\title{
The Layers of National Innovation Systems: The Historical Evolution of a National Innovation System in Norway
}

Olav Wicken

Centre for Technology, Innovation and Culture (TIK), University of Oslo.

Correspondence: olav.wicken@tik.uio.no

\begin{abstract}
The national innovation system (NIS) of Norway is characterized by diversity. This paper examines the multiple and heterogeneous historical processes, each defined as a path, that have given rise to such diversity. Each of the paths has involved specific types of social groups, organizations, knowledge bases, and institutional set-ups, and for each path a specific type of innovation structure has been developed. We define three main historical paths emerging from three major industrial transformation processes in Western history defined as Industrial Revolutions (Bruland and Mowery 2004). Each of these transformations created new industrial paths constituting a new layer in the economy. The Norwegian NIS is therefore described as the historical outcome of three diverse paths and consisting of three distinct layers. The creation of a new path does not indicate that the old paths of the economy remain static. Rather each path historically has undergone radical transformation processes in order to remain competitive in changing environments. The main dynamics of the innovation system are therefore linked to path transformation and path creation processes.
\end{abstract}

Version of 25.6.2007

TIK Working paper on Innovation Studies No. 20070601

\footnotetext{
*This paper is part of the project "Innovation, Path-dependency and Policy" (IPP) carried out at the Centre for Technology, Innovation Culture (TIK), University of Oslo with the support of the Norwegian Research Council (Contract no. 154877). However, the Centre, University and Research Council are not responsible for the content of the paper, which is the sole responsibility of the author(s).
} 


\section{Introduction}

The national innovation system (NIS) of Norway is characterized by diversity. This paper examines the multiple and heterogeneous historical processes, each defined as a path, that have given rise to such diversity. Each of the paths has involved specific types of social groups, organizations, knowledge bases, and institutional set-ups, and for each path a specific type of innovation structure has been developed.

We define three main historical paths emerging from three major industrial transformation processes in Western history defined as Industrial Revolutions (Bruland and Mowery 2004). Each of these transformations created new industrial paths constituting a new layer in the economy. The Norwegian NIS is therefore described as the historical outcome of three diverse paths and consisting of three distinct layers. The creation of a new path does not indicate that the old paths of the economy remain static. Rather each path historically has undergone radical transformation processes in order to remain competitive in changing environments. The main dynamics of the innovation system are therefore linked to path transformation and path creation processes.

\section{Path transformation: Small scale decentralized industrialization} How paths have been transformed over time can be illustrated by the development of the oldest path during the early 1900s. This path is characterized by small scale personal or family-owned companies using informal knowledge, and has been a core aspect of the nation's industrial and economic history. In primary production (i.e. agriculture, fishing, fish farming), in manufacturing industry, as well as in most of the service sector the 
characteristics of the first path are still important, and may be seen as a main characteristic of the Norwegian society. This path is central to the characterization of Norway’s economic history as “Democratic Capitalism.” (Sejersted 1993)

This path originates from the first Industrial Revolution, when most developments in Europe took place in small workshops, using traditional knowledge, and forms of organization. ${ }^{1}$ The small scale companies were closely incorporated and regulated by local norms and rules. This 'localism,' with a very large number of independent farmers and land owners, fishermen, traders, forest owners, ship owners, etc., became the political and cultural basis for a specific way of organizing economic activity in Norway. The ideal was - and to a large extent still is - small scale and rural economic units closely integrated in local communities, and citizens who were (are) self employed running their own businesses.

We may call this the small-scale decentralized path. ${ }^{2}$ Much of Norwegian history may be analyzed as reactions of society and politics when this path has been challenged. The first dramatic challenge took place in the late $19^{\text {th }}$ century, when the old path was no longer able to support the growing population in the Norwegian countryside. The period from the 1880 s to the 1920 s was a critical period when the Norwegian economy was forced to react to external pressure. Some old industries were strongly locked into path dependency processes and were not able to survive (shipping based on sailing ships). Many other “old” industries nevertheless exploited new forms of knowledge, organization and technology to transform themselves within the old social structure. These path 
transformation processes reformed and revitalized old industries (fishing, mining, the timber and woodworking industries, the modern shipping industry).

The long-term survival of the small scale decentralized path in the economy has depended on multiple processes of transformation through which new forms of knowledge and organizations have been incorporated into the existing forms of production. Today, small-scale Norwegian companies exploit both informal knowledge and science-based information in innovation processes and collaborate with other companies or universities/ research institutes to solve problems. Many small scale companies have succeeded in remaining or becoming competitive knowledge-intensive production units and organizations.

[BOX 1 ABOUT HERE]

\section{Path creation: large scale centralized industrialization}

The most important path creation process during the $20^{\text {th }}$ century is the evolution of a path dominated by large scale economic organizations. The large-scale company became the dominant form of economic organization beginning in the mid $20^{\text {th }}$ century in Norway, and this path has enjoyed strong political support. Particularly during the "oil age” of Norway’s recent history (since roughly 1980) a path characterized by large scale companies that are able to influence and shape their own environment (or institutional set-up) became strong. 
This type of production has a long history in Norway (particularly in mining), but only during the first two decades of the $20^{\text {th }}$ century that did it become an important element in the economy. It was during this period that the modern industrial enterprise (Chandler 1990) was introduced. In Norway, the emergence of large scale companies was closely linked to the development and use of electric energy exploiting water falls. The growth of an electricity-intensive industrial cluster strongly influenced Norwegian industrial policy toward natural resources during the second half of the century, and the emergence of the oil sector reinforced this policy focus. The large scale 'modern industrial enterprises' in Norway established science organizations (laboratories) and engaged scientists/engineers in innovation processes.

The emergence of a new form of industrialization with characteristics distinguishing it from the old path is called a path creation process. ${ }^{3}$ The new path became an important element in Norway's economy and society through a process involving both external actors (particularly foreign investors) and local actors and organizations. The Norwegian NIS is open, and external capital and knowledge was of crucial importance for the path creation process. The new layer in the economy involved new social groups (investors, engineers, scientists, managers, consultants, etc) and organizations that exploited new forms of knowledge (science, engineering knowledge, management knowledge, finance knowledge, law, etc.). The emerging groups and forms of knowledge became important for learning and innovation processes in the new path. 
The large scale form of industrialization influenced Norwegian national politics and therefore, the institutional environment of these industries. Particularly after WWII, Norwegian political institutions have encouraged the development of the modern industrial enterprise. This path became the core element of industrial policy making, and this policy focus was reinforced by the emergence of the oil sector.

\section{[BOX 2 ABOUT HERE]}

\section{New path as enabling sector: R\&D intensive network based industrialization}

The large-scale, centralized form of production became the basis for Norway's long term specialization in resource-based industries. A new path emerged during the last part of the $20^{\text {th }}$ century, when the old paths once more were challenged by the international development of new forms of production. Large scale hierarchical organizations were challenged by more flexible forms of production, and emerging technologies like ICT, biotechnology and new materials created both opportunities and challenges for old ways of production. This path creation process, however, has not yet produced the basis for new forms of economic specialization in the Norwegian economy. In contrast to Sweden and Finland, the new path was incorporated into the older paths, as many R\&D-intensive, smaller firms became technology producers and problem solvers for old industries (especially oil and gas) and the public sector. 
The new path creation process was closely linked to the emergence of electronics, computer production, telecommunications, and automation systems. Many of the new companies within these sectors may be defined as firms where the 'production unit had become a laboratory'. Although science in the large scale centralized path was limited to the laboratory, the new emerging path was characterized by a high level of $R \& D$ within ordinary production. In the Norwegian context most companies were small, working closely with research institutes, universities, public procurement agencies, governmental organizations, and other companies. They were part of networks of organizations where new institutions (rules of the game) were established as the outcome of long-term interactions involving both private and public actors. The emerging $R \& D$ intensive network based type of industrialization was not directly related to exploitation of natural resources, but many of the early companies in the emerging path developed and produced technologies related to Norway's resource endowment (telecommunications, satellites) or produced inputs to resource-based industries (automation systems, detection and communication for fishing and shipping etc.).

The primary factor in the emergence of Norway's 'high-tech' industries was the buildup and transformation of the oil and gas sector, for which high-tech firms served as an enabling sector. The oil and gas sector provided a profitable domestic market for companies that could assist in solving challenges posed by the natural environment and political regulation of offshore petroleum production. The emergence of this third path of industrial development thus became an important element of the innovation structures for small-scale decentralized as well as large-scale centralized form of production, and 
contributed to the transformation of large parts of the economy during the last decades of the $20^{\text {th }}$ century. The firms in this third path supported industries which enabled other sectors of the economy to remain competitive in a global economic environment.

[BOX 3 ABOUT HERE]

\section{The small scale decentralized path}

The influential position of the small-scale, decentralized form of industrialization in the contemporary Norwegian economy is the outcome of a long historical process dating back to the early industrial society. As late as the first half of the $20^{\text {th }}$ century, most of Norway’s population lived in rural areas and worked in industries closely connected to developing and extracting natural resources. Most production units were small, and controlled or owned by families or groups of families in local communities. The majority of the population was farmers, many of whom combined farming with other employment in fisheries along the coast and forestry in inland regions. Norway may be described as a society where a majority of the population were landowners (although a rural proletariat of renters grew during the mid- $19^{\text {th }}$ century) or had access to natural resources that provided a basis for family income, mainly fishing. With few exceptions ownership was widely distributed and locally controlled. Norway was a society dominated by an independent small scale 'petit bourgeoisie' that was linked to primary industries extracting natural resources. (Sejersted 1993) 
The strong position of small-scale industrialization in Norway was the outcome of industrialization during the $19^{\text {th }}$ century. Productivity growth during the first half of the $19^{\text {th }}$ century was closely linked to improved efficiency in agriculture, particularly mechanization and the introduction of new crops (e.g., the potato). Economic change in Norway during this period was linked to innovative activities that relied on knowledge from local and external sources. Local blacksmiths established small workshops to supply farms with equipment and machinery. In large parts of the country, small-scale capital goods firms were established to supply the traditional export sectors. This became the institutional basis for the transformation and development of the economy.

These processes of change were not concentrated in any specific part of the economy. Similarly to the Industrial Revolution in Great Britain, Norwegian industrialization included technological change in large parts of the economy, including old industries like fisheries, agriculture, forestry, and mining, as well as the emerging manufacturing sectors producing textiles and capital goods. To a large extent the productivity improvements and economic growth resulted from small scale or marginal improvements that did not demand radical organizational or social change.

\section{Informal knowledge and social learning}

Innovation within the localized and small scale economy was based on learning processes that involved interaction between people locally or internationally, as well as collective or cooperative forms of resource allocation within local communities to initiate new production activities. This reliance on the local community for industrial development in 
Norway has been labeled localism. (Kjeldstadli, Myklebust and Thue 1994) The importance of local civil society, local organizations, and institutions was reflected in the many formal and informal institutions for sharing knowledge within the local community. Learning a skilled trade was common among young people from the earlier phases of industrial development, and this artisan-based tradition supported the establishment of small independent workshops. Trained young people often established their own workshop, creating a substantial group of self employed workers. Many examples indicate that it was common for young people to visit local workshops or small factories in order to learn a specific part of a production process, and then use this expertise to set up a new company. (Kjeldstadli and Myhre 1995)

There are also many historical examples of "learning by doing” by workers that resulted in small or incremental technical improvements, some of which were patented. This type of incremental innovation may improve productivity significantly over a long period of time, and a number of Norwegian companies established specific institutions to encourage employees to participate in this type of innovative activity. (Wicken 1984) The key sources of technical innovations in this path were the capital goods industry and workshops within these companies. Firms in the engineering industry became organizations that addressed the problems of other producers. (Rosenberg 1972) The mechanical workshops employed people with broadly applicable technical skills, mekanikus. Although they had no formal education, most had wide knowledge of various aspects of mechanical engineering. These workshops became small but important 
organizations for improving companies’ production technology and for solving other costumers' technical problems.

These local mechanical engineering workshops created the basis for user-producer interactions that were important for long-term industrial development within this path. Farmers, fishermen, ship-owners and others continuously communicated with local mechanical workshops on how to improve production technology or solve specific problems for individual users. ${ }^{4}$ When a new solution was found, the workshop became a diffusion centre that could distribute the new technology to other users.

The learning processes linked to this path were largely localized and specific to local traditions, problems, and knowledge bases. But international sources of knowledge also were important in cases where local knowledge was not sufficient for solving problems of great importance for the local economy. Norway is located nearby the earlyindustrializing regions of England and Scotland, and is close to commercial centres in the Netherlands, Denmark and Sweden. Systematic search for knowledge - including espionage - was supported both by national political authorities and local municipalities. (Bruland 1991) The openness of Norway’s innovation structures thus created opportunities for more radical transformative processes.

There was little if any direct relationship between scientific knowledge and innovation in Norway or elsewhere before c. 1870 . But most of the Norwegian population was literate in the beginning of the $18^{\text {th }}$ century, and technical and scientific popular literature became 
available in the mid $19^{\text {th }}$ century. Priests in some regions observed that people were engaged not only in reading about new mechanical and scientific inventions, but also discussed how the new knowledge could be used locally.

\section{Institutions defining civil society in the small-scale path of industrialization}

The independent self employed farmer (more accurately, the peasant) became the hero of the Norwegian nation during the nation-building period of the $19^{\text {th }}$ century. Strong institutions were established to secure the equitable distribution of property among citizens, mainly by regulating the control of and access to natural resources. The core institution was the odelslov, which regulated how land could be transferred from one owner to another and basically made land a non-market commodity. Farm land was to be handed down from father to son and could not be sold out of the family. The free access to rich fishing resources along the coast created a large social group of independent fisherman-farmers that owned some land and parts of a fishing vessel and fishing gear. Only in mining and forestry could accumulation of capital into few hands take place and challenge the social position of the small-scale independent producer.

The dominating aspect of 'localism' in the Norwegian economy was the local savings banks. They emerged during the $19^{\text {th }}$ century as a response to the demand for credit from the rural petit bourgeoisie and supported farmers, fishermen, or small industrialists with money for small scale investments. The banks played an important role in directing resources into local industrial projects, often being the main source for funding of small scale projects. Only during the 1990s did the system dominated by small local banks 
directed towards local industrial development activities break down. While it lasted, the local savings banks supported the dominance of the individual or family owned company in the organization of economic activity.

The limited capital base for local industrial activities produced other systems for collective mobilization of resources that were common in the expansion of sectors such as shipping (the partsrederi system) and fishing (shared ownership of vessels). The system of partsrederi was the main organizational form behind the success of the Norwegian shipping industry during the $19^{\text {th }}$ century. In this system, members of the local community provided different types of resources for the construction and commercial operation of a ship. Depending on the input, each participant would own a share of the shipping company which owned the ship. As profit was realized, they were paid according to the share they each owned. (Bergh and Lange 1982) A similar system was used to mobilize local resources in fisheries in many places along the coast. (Sundt 1975)

The strong role of local institutions and organizations for industrial development meant that the emerging industrial society was deeply embedded in the existing society. The behavior of entrepreneurs and industrialists was shaped by the values and norms of local society, even when new economic activities also challenged established norms and values. The local basis for funding of a company, as well as the company's reliance on the local community for knowledge and learning, meant that no individual actor could become dominant within the existing social structure. The individual company depended on local collective or co-operative organizations and institutions for survival and for 
success, relying on them for mobilizing resources, interactive learning, and co-operative organizations for procurement of inputs. The firm had to adapt to local 'rules of the game’.

This local basis for industrial development made the rural petit bourgeoisie a strong political force within the parliamentary system introduced in Norway in 1884 . The Liberal Party (Venstre) represented small scale industry and local communities, and became the dominant Norwegian political force during the first half of the $20^{\text {th }}$ century. A Norwegian historian defines the period c. $1884-1940$ as the Era of the Liberal Party, emphasizing the ideological hegemony of a specific type of policy. (Slagstad 2001) The path characterized by small-scale independent entrepreneurs and business people deeply embedded in local communities and institutions gained a strong position in Norwegian society and politics during first half of $20^{\text {th }}$ century.

\section{Transforming and reproducing the old path}

New forms of production emerged internationally from the late $19^{\text {th }}$ century and challenged the old path of Norwegian industrial development. The old export sectors were challenged by new technologies, particularly by the development of steam vessels. Modern steam-powered ships challenged the Norwegian sailing fleet, new types of vessels challenged the old form of fishing (wood-and-sail technology), and modern transport technology was an important factor behind the deep crises of agriculture all over Northern Europe. Steam engines also challenged the old system of the forestry industry based on small local saw mills using water power. 
These challenges were met in different ways. In many cases the old industries adapted to the new economic environment through significant restructuring that relied on new technologies and knowledge bases. Agriculture, fishing, manufacturing industry and shipping underwent a transformation between the 1880s and the 1930s, some of the old industries established new institutional set-ups that aided their survival.

Agriculture went through what is labeled 'Det store hamskiftet' (The Great Transformation), as a result of which cattle became the main production technology and milk the main product. Two policies supported the survival of the country's most important industry during the early $20^{\text {th }}$ century. The Liberal party supported an innovation policy or productivity policy to increase efficiency and improve the ability of farmers by to compete on open markets. These policies expanded public investments in agricultural science and education, as state and local governments supported local farming education (Landbruksskoler), national research centres and higher education institutions (Ås). Programmes for diffusion of production technology and increased mechanization were introduced. The research centres developed a new breed of cattle that was well adapted to the Norwegian local environment that produced milk and meat of good quality (Norsk Rødt Fe), and developed other crops to increase productivity. (Nielsen et al 2000) Norsk Hydro produced artificial fertilizers in large quantity that increased food production significantly. In this way structures and systems for diffusing scientific knowledge and science-based technology were introduced into the primary sector. 
However, in the interwar period the innovation or productivity policy failed to solve the problems of Norwegian farmers. The price of the main product, milk, dropped dramatically and by the early 1930s the crisis had become urgent. The solution was based on the Farmers’ Party policy (lønnsomhetslinjen) that sought to control the market. (Bjørgum 1968) The Storting passed a law that forced all milk producers to sell the milk to one monopolistic (cooperative) organization, prohibiting price competition among milk producers. (Furre 1971) The new distribution system increased income for a majority of the farmers. The agricultural sector remained a small-scale and decentralized production system, but the distribution system increased its scale and became more concentrated. Agriculture's political success kept the old path alive without major transformation of production during the second half of the $20^{\text {th }}$ century. Milk production distributed through a centralized system still dominates Norwegian agriculture.

\section{[BOX 4 ABOUT HERE]}

The transformation of the fishing industry illustrates how the old path mobilized political, social, technical and organizational resources in order to survive. From the 1890s the traditional wooden sail vessels were challenged by foreign (British) steel vessels using steam engines. The government introduced laws to protect small-scale coastal fishing, particularly in the cod fisheries of northern Norway. These laws, however, did not prevent economic decline, as Norwegian fishermen, like farmers, experienced a prolonged period characterized by low income and poverty. A number of public 
initiatives were taken to improve productivity and production, relying in part on R\&D. The Marine Research Institute (MRI) became world leading in fish demography, mapping the movements of fish and wiring the information to fishing communities. (Schwach 2002) In Bergen, modern meteorology was founded by Wilhelm Bjerknes, and the meteorologists informed fishermen of when it was dangerous to go out to sea. (Friedman 1989) MRI introduced a new scientific practice, working closely with fishermen and communicating with fishing communities at sea during the fishing seasons. There was close interaction between scientific research and the end-users of the research.

Modern technology created the basis for a gradual transformation of Norwegian fishing, beginning with the introduction in the early $20^{\text {th }}$ century of light and cheap combustion engines that could be used on small wooden vessels. Norwegian fishermen and fishing communities had long sought an engine design that was adapted to the small boats in the North Sea region. By the 1890s light combustion engines were developed in Denmark that were well suited to the existing Norwegian fishing fleet. Thousands of Norwegian fishing vessels quickly introduced small and inexpensive engines, and engines for fishing boats became a major Norwegian growth industry until roughly 1920, relying on the output of a large number of small workshops producing engine designs that were copied from other producers. A rapid learning process improved the quality of the engines, and more efficient engines opened new opportunities for development of the industry. 
Mechanization of the fleet made it possible to use heavier fishing gear, and larger nets were introduced. The 'wood-and-sail' technology was transformed into a 'wood-andengine’ technology, but the fishing industry remained small-scale with low capital costs and ownership of ships continued dominated by fishermen in rural villages. However, over time some fishermen ordered larger vessels and gradually a fleet of modern, larger fishing ships for ocean fishing emerged in parts of the country. Fishing vessels continued to be owned by the fishermen, constructed by yards along the coast, and local workshops produced engines, fishing gear, packaging of fish for export etc. The fishing industry remained an important part of the coastal economy, one that was still characterized by local learning and marginal innovative improvements.

The 'wood-and-engine' vessels were not able to increase fishing volumes as rapidly as the more cost-intensive steel-and steam technology. Britain passed Norway in total fishing volume during the 1930s, but resistance against large scale trawling technology remained strong in the Norwegian fishing industry. The increase in fish volumes on international markets reduced prices, and during parts of the 1920s and 1930s, there were deep economic crises in many fishing communities. The solution to the problem was similar to agriculture. The Storting (1936) passed a law which forced all fishermen to sell the fish to a monopolistic organization (Råfisklaget). At the same time the industrial capacity to expand processing of fish (fish meal, fish oil) increased, providing an alternative market for fish during periods with very low international prices. 
In manufacturing industry, the old path was strengthened through a dramatic structural transformation during the interwar period. The recessions during parts of the 1920s (currency crises) and during the 1930s (international recessions) forced a number of established factories to close down or to reduce production volumes, creating large-scale unemployment within the workforce in manufacturing industry (approximately one third). In parallel with this reduction in urban manufacturing production, a large number of small, rural workshops were established in a number of sectors (wooden industry, clothing, furniture, metal products, etc.). The new companies exploited social as well as technological opportunities. Social crises and weak unions in rural areas kept wages low, and the emergence of cheap, small, flexible and efficient machinery using electric motors reduced capital costs. (Sejersted 1982) This rural industrialization process was supported by public institutions. The government established a state institute for technology (Statens Teknologiske Institutt) in 1916 that diffused knowledge and technology to small companies, and local offices to support small start-up companies with market and product competence (småindustrikontor) were established in many regions. During the inter war period a large part of manufacturing industry became incorporated in the small-scale decentralised path. (Refsdal 1973)

In total, by the mid $20^{\text {th }}$ century the small-scale decentralized path still retained a dominant position in the Norwegian economy. Norway was far from an urban society, and the economy was still characterized by a large number of very small companies. However, the small-scale decentralized form of industry had been modernized and had increased its productivity. New technology and new knowledge bases (science) had been 
introduced and were widely used. Technologies regarded as core elements of the Second Industrial Revolution, electricity and the combustion engine, were used to modernize old industries. In this way, core aspects of the old path survived with a large group of independent producers exploiting natural resources, and considerable political power remaining in the hands of the rural petit bourgeoisie.

\section{Lock-in and the creation of new industries}

For some of the old industries the transformation during the early $20^{\text {th }}$ century resulted in more radical change and a move away from the old path. This was the case for much of the old shipping industry. Sailing ships had dominated the Norwegian shipping industry until WWI, but by that time were no longer competitive. This had a great impact on the coastal rural economy, as the old shipping industry disappeared and with it much of the small-scale shipbuilding industry that had specialized in the construction of wooden sail ships.

In shipping, the technological transformation was much more radical than in fisheries. Modern ships used steel ships with steam or diesel engines, and a new Norwegian shipping industry emerged (mostly) outside of the old one. The new shipping companies were established in urban areas, mostly around Oslo and in Bergen. Many companies were not closely incorporated into local communities, but emerged from interactions between individual Norwegian entrepreneurs and large international corporations. This is most evident in the dynamic new sector of oil transport. Many of the international oil producing companies had traditionally owned a fleet of oil tankers and transported its 
own oil. During the inter war period transport was outsourced, and Norwegian entrepreneurs procured oil tankers and entered into long-term contracts with the oil companies to transport their oil. (Andersen 1989)

During the interwar period, a new large scale and capital intensive ocean shipping industry emerged that exploited distant natural resources. In a short period of time, for example, pelagic whaling became an important export sector. Entrepreneurs in the urban Oslo fjord region raised capital to construct large steel ships with steam engines and modern capital-intensive technology to hunt for whales in the Antarctic region. The industry was extremely profitable, and in a short period of time a large ocean hunting whaling fleet was established. A number of new knowledge bases were introduced into the modern factory fleet, modern technologies were exploited, financial institutions involved, and a social group of whaling capitalists grew very rich. Whaling technology was developed and produced locally. There were connections between whaling and shipping, establishing a group of capitalists that operated with modern technologies on a global level. Both industries were based on Norwegian knowledge and traditions of sea transportation and extraction of natural resources.

\section{Path creation: The large-scale centralized path}

The period between 1880 and 1920 has been labelled by some historians the Second Industrial revolution, characterized by the introduction of new sciences and technologies (electricity, chemistry, combustion engine, interchangeable parts) that became important for industrialisation during the $20^{\text {th }}$ century. (Landes 1970) Other historians have 
emphasized the emergence of large-scale production units and organisations (modern industrial enterprise (Chandler 1990) or large technological systems (Hughes 1983). Norwegian historians have argued that the transformation found in many other Western countries is not reflected in the Norwegian experience. This was the period when Norway took a different path from those of Germany, USA or Sweden. Norway’s economy remained dominated by small-scale decentralised production and Norwegian politics were heavily influenced by the rural petit bourgeoisie, in what has been labelled “Democratic Capitalism.” (Sejersted 1993)

Recently the historian Knut Sogner has challenged this perspective on Norwegian history, arguing that even in Norway the new technologies, industries and social groups characteristic of the Second Industrial Revolution in other nations emerged. Norway also experienced the development of a rich bourgeoisie controlling large capital-intensive industrial organizations that exploited modern science and technology. According to Sogner, this social group became influential in society and politics, and exercised considerable power over Norwegian industrial, economic and political development throughout the $20^{\text {th }}$ century. (Sogner 2001, 2002, 2004) The emergence of this new path in the economic development was closely linked to the exploitation of Norway's natural resources. During the two first decades during the $20^{\text {th }}$ century, the development of electricity production became the main force for large-scale industrialization, and during the last two decades of the century, oil and gas played the same role. 
Even before the $20^{\text {th }}$ century, Norway was home to a few large companies linked to extraction of natural resources, particularly in mining. Mining created demand for more capital-intensive production and was the basis for small scale urbanization in isolated regions. The silver mines in Kongsberg made the town one of the largest of the small urban communities in Norway during the $18^{\text {th }}$ century. (Berg 1998) A number of mines were opened all over the country that exploited deposits of silver, copper, sulphur, iron, and nickel. The growth of Norway's mining industry also influenced higher education in Norway, through the establishment by the Danish state of the Mining Academy (Bergverksakademiet) in Kongsberg in 1757.

The emergence of the modern large-scale form of industrialization in Norway during the early $20^{\text {th }}$ century was the outcome of technological innovations that turned waterfalls into a source of electrical power. Beginning in the 1870s, innovations in what became known as electrochemistry and related technologies made possible the use of electricity for the production of metals (steel, aluminum, others) and chemical processes (including wood processing). Norway's mountainous terrain gave the nation the second largest potential for electricity production in Europe; only Russia had a greater potential. Norway became a potentially important major source of cheap electricity for industrial applications within Europe. Many investors saw the economic opportunities to exploit Norway's waterfalls and establish large-scale electric-power generation facilities as the basis for large-scale industry projects. During the historical period defined as the 'New Imperialism' European and American investors searched for profitable investments in various parts of the world. Access to natural resources, especially in a politically stable 
part of Europe, attracted investors during the late $19^{\text {th }}$ century no less than it would in the oil and gas era of the 1970s and beyond.

The emerging new path was linked to two linked but differentiated economic processes. First was the extensive construction of electricity-generation works linked to waterfalls. Some of Europe's largest electricity works were constructed in Norway, in addition to a large number of smaller units. A gradual development of a transmission system for electricity all over the country was constructed. (Thue 1994) The development of electric power as a large technological system took a different form in Norway from that of the USA and other countries. The main users for the large scale electricity works in Norway were not cities and local population, since consumer demand was insufficient to utilize the vast supply and since most large waterfalls were far away from urban centres. Instead, the geographic pattern of investment in electricity-generation systems was concentrated in isolated rural sites to support mining and metals-processing industries. A similar - but even more large scale - investment and construction process took place with the build-up of the offshore oil and gas sector from the 1970s (Engen 2007).

The expansion of large-scale electricity production created a search for users of vast amounts of energy. The exploitation of hydropower thus provided a second path of development of large-scale centralized industrialization in Norway, and became the basis for electrochemical industry (fertilizers), wood processing (paper) industry, and electrometallurgical metals processing (aluminum, ferro) as well as large petrochemical plants during the last part of the $20^{\text {th }}$ century. The exploitation of electricity in the $19^{\text {th }}$ 
and early $20^{\text {th }}$ centuries, as well as oil and gas in the late $20^{\text {th }}$ century, outside of major Norwegian urban centres promoted geographically decentralized pattern of development of large-scale industries in Norway, a trend that was been promoted by policy initiatives during the second half of the century. This was the core of the path creation process of large scale centralized industrialization.

Cheap electricity also contributed to the transformation and expansion of Norway's mining industry. New electricity-based refining technologies made the exploitation of low-grade mineral sources profitable, and the new methods were introduced on a broad scale in Norway in the early $20^{\text {th }}$ century. Since mines also were located outside of Norway's main urban areas, this wave of innovation in mining strengthened the geographically decentralized pattern of development of large-scale production units within the country. Norway experienced the establishment of many small industrial towns and expansion of some of the older small towns based on the construction of one or a few new factories, mines or electricity works: Rjukan, Notodden, Odda, Sauda, Høyanger, Arendal, Kristiansand, Sarpsborg, Skien-Porsgrunn, Varanger, Ny Ålesund, Sulitjelma, Mo i Rana, Mosjøen, Folldal, Årdal, Sunndal, and others are examples of the industrial towns established in various parts of the country. (Wicken 2004)

By the beginning of the 21st century most of Norway's resource-based exports are based on energy related sectors. Oil and gas dominate all statistics, and metals is the second largest export sector. This path has become the most influential part of the economy in shaping national policies, including industrial and innovation policy. 


\section{New social groups in the new form of industrialization}

Innovation within the older Norwegian small-scale path was based primarily on informal knowledge and local learning processes, although these processes were gradually influenced by the growth of a national science-based knowledge infrastructure. Innovation processes within the emerging large-scale path, however, rely on stronger links among higher education, formal science and industry. In Norway, engineers, scientists and investors became main actors in the development of new processes and companies during the first decades of the $20^{\text {th }}$ century.

Beginning in the 1890s, Norwegian individuals and companies who were well informed about European technological developments attempted to achieve control over Norwegian hydropower resources, in the expectation that the value of these sites would increase rapidly. One of the more important of these entrepreneurs was the engineer Sam Eyde, who managed to get control over the hydropower rights associated with a number of large waterfalls. Eyde ran a construction engineering firm and saw profitable potential in the construction of electricity works and also sought out potential users of the electric power generated at these sites. Sam Eyde was representative of one of the new social groups linked to large-scale industrialization. He belonged to a family of ship-owners and had received his engineering education in Berlin. This combination of an upper-class family background and foreign technical education was common within a large group of young men involved in Norway's large-scale industrialization path of the late $19^{\text {th }}$ and early $20^{\text {th }}$ centuries. Norway did not have a national civil engineering university until 1910 , which meant that many of the nation's engineer-entrepreneurs of the early $20^{\text {th }}$ 
century were trained abroad. This social group was well aware of foreign technological developments and maintained technical and economic contacts in Europe. They had the social and technical competences to operate internationally.

In addition to engineers, scientists, often trained at Norway's only university in Oslo, became involved in the large-scale industrial processes of the early $20^{\text {th }}$ century. There was a tradition among many of the Oslo university professors of direct involvement with company or industry development processes. During the period c. 1890-1920, Oslo University became more focused on research in natural sciences. New scientific areas emerged from the university professors, and others contributed significantly to older areas. ${ }^{5}$ A common feature of the professors’ work was a direct linkage between theoretical development and practical use in close collaboration with scientists in other countries (Gulbrandsen and Nedrum 2007a). A classic example of this research approach was the experiments of Professor Kristian Birkeland in understanding the Northern Lights, which resulted in his development of an electric gun. In order to finance his research, he established a company to market the gun internationally for military purposes. The gun was not profitable, but Birkeland's commercial efforts resulted in the development of a relationship with Sam Eyde, who exploited the electric gun as an instrument to attract nitrogen from the air. This famous case illustrates that the involvement of university faculty with industry during this period less often involved the exploitation of basic scientific theories than the application of their engineering skills. 
Birkeland had a technology and Eyde controlled waterfalls. Eyde’s entrepreneurial efforts attracted another new social group into Norwegian industry: large international banks and investment groups. The Swedish Wallenberg family and their bank (Enskilda) became important investors in the development of waterfalls and large scale industry. They were involved in the establishment of companies for exploitation of the Birkeland-Eyde technology and succeeded in attracting the Parisbas bank to invest in the establishment of the early production plants of Norsk Hydro (established 1905). (Andersen 2005)

The establishment of Norsk Hydro was crucial for long-term industrialization in Norway. The case illustrates the dependence of this type of industrial development on relationships that spanned national borders, in addition to Norway’s developing technological competences in a number of areas. Small companies like Eyde’s engineering firm, Birkeland’s marketing company, law companies, financial organizations, etc. collaborated with one another (and with foreign firms or investors) in establishing new industrial companies and in developing new processes. They also collaborated with the university in Oslo (and NTH after 1910) as well as with political authorities. Sam Eyde’s establishment of Elkem in 1904 created an organization that served as an entrepreneurial as well as a technological experiment for the new industries in Norway. Elkem "spun out” a number of new electricity based companies ${ }^{6}$ and developed new processes for the electrochemical industry. The firm’s most important innovation was the Söderberg electrode, introduced during WWI, which became a major export and was widely adopted in electricity-based smelting processes, including aluminum (Moen 2007). Elkem became a major engineering and technical consultancy company for electrochemical firms 
throughout the world. (Sogner 2004) A number of other Norwegian companies became involved in construction and technological development within electricity production and the electricity-based industries. Overall, Norwegian entrepreneurs, engineers, and scientists proved quite capable in developing the new large scale organizations and production units within the "local society" foundations of Norway's political and economic order.

The establishment of the new industries were closely linked to knowledge and resources from other countries. The Norwegian economy and innovation system were open, and openness was crucial to the establishment of the new path. In cases such as aluminum, most of the technology, investments and skills exploited within Norway were transferred from abroad, and firms active in these sectors had relatively weak links with the wider national economy (Moen 2007). In most cases, a combination of internal competence and resources combined with foreign actors, who contributed financial resources and broad engineering systems competence and technology. The wider economy had the capacity to absorb and incorporate knowledge and resources from abroad into local institutions and organizations.

[BOX 5 ABOUT HERE]

\section{Establishment of a new institutional set-up}

The small scale decentralized form of industrialization had a strong position in Norwegian policy and ideology until WWI, and the public opposition against large scale 
industrialization was particularly significant during the early 1900s. However, large-scale industrial development was favoured by a social and political elite, and a group of industrialists and politicians worked intensively to support the path creation process. After WWII 'New Labour' introduced a number of new institutions to promote the largescale path of industrialization.

The development of the electrical industry sector was soon supported by public and political decisions that influenced the direction and structure of large-scale industrialization. In 1899, the first law was passed to regulated public procurement, and gave priority to national companies in public (municipalities and state) construction of electricity works. The law was updated in 1921 in order to strengthen procurement policies as industrial policy. These policies became an important component of an 'infant industrial policy’ for the capital goods and construction industries in electricity development.

The most important policy affecting the direction of the large scale industrial path was the Concessions Laws, which became the core element in national policymaking between 1906 and 1917. The laws regulated the ownership of natural resources like waterfalls. A major provision of these Laws was the requirement that non-public owners return ownership to their sites to the state after 60 years (hjemfallsrett), reflecting the ideology that natural resources belonged to the society (represented by the state). The laws secured preference for Norwegian citizens to control waterfalls during the crucial period for the establishment of large-scale industrialization based on electricity. Although they favored 
national control of a critical natural resource, it has been argued that the Concession Laws was liberal in a wider European perspective and therefore not detrimental to capital import to the new sectors. (Lange 1977)

The Concessions law also shaped large-scale industrialization during the oil age. Oil companies applied to the Norwegian state for offshore drilling rights, and the state handed out concessions for specific geographical areas to oil companies (Engen 2007). This system provided powerful leverage through which the Norwegian government influenced the behaviour of oil companies, ensuring that foreign companies used Norwegian suppliers, contributed to training Norwegian companies and individuals, and became involved in technology development processes. The Technology Agreements, which were introduced in the late 1970s to encourage foreign oil companies to invest in R\&D in Norway, built on this policy foundation (Wicken 2007).

The government also regulated the development of energy-related large-scale industrialization by controlling access to key inputs, such as electricity and capital. From WWII until 1990, the state controlled the construction of new electricity works and oversaw a system of long-term contracts with energy-intensive companies that ensured electricity supplies at predictable, relatively low, prices. The state also supported this type of industrialization by funding investment through agreements with major international corporations in core industries like aluminum, and direct public funding. Through ownership in companies like Norsk Hydro, ÅSV, Statoil, Jernverket and mines, governments influenced investment and development strategies. An example of this was 
the collaboration between ÅSV and Raufoss Ammunisjonsfabrikk to produce aluminum products for the car and construction industries. The use of public investment funds for industrial policy created new opportunities for the public sector to influence Norwegian industrialization (Wicken 2007).

The public sector also supported the development of institutions for training, education and research that supported the large-scale form of industrialization. The establishment of a national technical university (NTH 1910) was a significant development in this area (Gulbrandsen and Nerdrum 2007a). As early as WWI, the Norwegian state introduced a new institution (Råvarelaboratoriet ${ }^{7}$ ) to promote research on natural-resource development. Not until the post-WWII period, however, did Norway establish research organizations and institutions that promoted collaboration between large companies and public (or semi-public) research organizations. The reconstruction of NTH after 1945 also included a reorganization to strengthen the ability of the technical university to support Norwegian industrialization in areas like chemistry, metallurgy, and electricity. (Hanisch and Lange 1985) The close relationship between Norsk Hydro and the public research institutes SI and IFA and later the interaction between national oil companies (Statoil, Hydro), and Norwegian research institutes (IFE, RF and Sintef) are examples of the public sector's promotion of learning and development processes in industry (Gulbrandsen and Nerdrum 2007a).

The large scale centralized form of industrialization shaped the long term development of the Norwegian knowledge infrastructure, the financial sector, and important aspects of 
policymaking, in addition to Norwegian industry. Large parts of the Norwegian capital goods industry, ICT, knowledge intensive business services, and the public research institutes focused their marketing efforts on large-scale companies within Norway's resource-based industries. This tendency was particularly pronounced with the advent of the offshore petroleum sector. In a short period of time all of the larger Norwegian shipyards moved into the expanding and profitable offshore production sector. Only the smallest yards in some regions on the Western coast continued with shipbuilding (Engen 2007), and after the 1980s, many of these shipyards became involved in the development and construction of special ships for the offshore sector, i.e. supply ships and LNG ships. By the 1990s, most of this industry had become part of the offshore sector. In a similar fashion, many research institutes became dependent on technology projects associated with the offshore sector. Statistics indicate that a significant part of the production of the engineering and technological industries, as well as knowledge-intensive services, is directed towards the offshore sector and the same is true of most of Norway's high-tech industry. (Grønning et al 2006) A large (and perhaps, growing) part of the knowledgeintensive sector of the Norwegian economy therefore is linked closely to the oil and gas sector.

Learning processes in the large-scale centralized form of industrializations differed from that of the small-scale development path discussed earlier. The large-scale companies depended much more on formal and science based knowledge, on collaboration between formal organizations, and the role of central state institutions and organizations remained crucial. In addition, the development and innovation processes most often involved 
foreign actors and resources. An important aspect of the innovation process in many of the large scale companies was that the companies employed people with higher education in science and technology and also established specific organizations for development processes, laboratories.

\section{The role of science in innovation and the industrial laboratory}

Higher education and science entered industry in new forms after the late 1800s in various ways, e.g., through formal training for would-be inventors; through organizations outside the company (such as universities) that provided formal training and research; and by bodies of empirically grounded, codified scientific and technological knowledge internal to the firm. (Bruland and Mowery 2004) This was also the case for Norway. Would-be inventors and entrepreneurs in the "large-scale” path often were trained abroad. Norway also strengthened national training and research capabilities within the higher education systems. (Gulbrandsen and Nerdrum 2007a)

Some Norwegian companies established in-house research capabilities during the pre1940 period, and by the outbreak of WWII, approximately 400 people worked in industrial laboratories, most of them in the large scale process industries. Norsk Hydro remained the most important $R \& D$ performer in Norwegian industry throughout the first half of the $20^{\text {th }}$ century. Analyses of Norsk Hydro's research strategies indicate that the firm followed two main innovation strategies: (i) developing new processes and new natural resources, and (ii) improving existing processes. Each of these strategies involved different types of external interactions. The development of new processes or products 
demanded wide areas of knowledge and involved the development of new electrochemical process technologies. An example of this strategy is the lengthy effort by Norsk Hydro to produce magnesium from sea water, a project that began in the interwar period and continued for many decades. This technology development strategy normally included collaboration between the company's laboratory and scientists in external organisations. (Andersen and Yttri 1997)

The second strategy, improving efficiency in processes that were already in use within the company, demanded close collaboration between company researchers and production personnel. These projects often involved the company's core competences and therefore normally less frequently relied on collaboration with external organisations. (Andersen \& Yttri 1997) The success of these projects depended to a large extent on good internal relationships among managers, engineers and workers. Indeed, the quality of firms' industrial relations became important for innovation and productivity in parts of the energy intensive industries (Sandvik 2004)

During the $20^{\text {th }}$ century, the relative importance of these two strategies within and among Norwegian firms in the large-scale sector has varied. During some periods the companies have chosen to give priority to process improvement, and in other periods the companies have focused on new products or processes, and these shifting sentiments were linked to broader beliefs regarding the key factors in competitiveness and growth. Although the 1980s were characterized by a search for new sectors and products, the period after the 
early 1990s was dominated by process innovation that sought to reduce cost and a focus on 'core activities'. (Andersen and Yttri 1997)

The firms in the large scale industrial sector constitute a major part of Norway's industrial R\&D system, and therefore are important actors in industrial research policy. Norsk Hydro, Statoil and other large resource based companies are the largest R\&Dperforming companies in the economy. However, from the 1960s a new type of company emerged which was smaller but far more R\&D-intensive. These companies flourished during the 1970s and 1980s in Norway, and after a difficult restructuring period during the 1990s, remain important industrial R\&D performers.

\section{Path creation in "enabling" industries: The R\&D-intensive network-based path}

Beginning in the early 1960s some groups linked to the Norwegian R\&D infrastructure argued that Norway's future welfare and growth could not be based solely on the resource-based and energy-extensive industries, i.e., on the large scale centralized industrial path (on the history of ICT industry, Sogner 2007). According to this argument, these industries could not continue their growth rate, and new industries were needed to compensate for the reduction in growth in the old, mature industries. This idea was presented in a document from the industrial research council (NTNF 1964).

The NTNF document from argued that Norway had to invest more heavily in R\&D to support all types of industries, but in addition, that investment in selected emerging 
technology areas would support the creation of new, faster-growing industries. Since WWII, technologists connected to research institutes and the research council had been advocates of nuclear energy, arguing that the future expansion of the energy-intensive industrial path depended on cheap energy, and nuclear energy would ensure that these industries remained competitive. (Randers 1953) The policy introduced in the mid-1960s promoted other emerging technologies like electronics, computers, regulation technology, and telecommunications, and the idea that these or other emerging technologies would become new industries gained support during the 1980s. At this time specific policy instruments were established for re-industrialisation strategies that attempted to exploit emerging technologies and knowledge areas. (Targeted Technology Areas, Wicken 2007)

The policy initiatives of the mid-1960s sought to support the growth within Norway of a new form of industrial production that was already well established in the USA. In the USA, the new form of production represented a fundamental change from an economy closely linked to its natural resource endowment (as US economic development through most of the pre-1940 period had been) to an economy that more "intensively exploited a burgeoning US ‘endowment’ of scientists and engineers” (Bruland and Mowery 2004). This change was illustrated by the emergence of new industrial sectors like information technology that were not directly linked to natural resources and the natural environment. The dynamics of these industries involved different types of learning and knowledge than earlier types of industrial production. (Wicken 2007) The creation of this type of industrial development in Norway was the goal of an influential group called the modernizers. (Wicken 1994) 
[BOX 6 ABOUT HERE]

\section{Innovation: The production unit as a laboratory}

The new form of industrial production involved formal knowledge and research in innovation processes in a more radical way than did the older science-based industries. Innovation in the large-scale, science-based industries involved industrial laboratories that were separated from production operations. In the new form of industrialisation, however, the production unit itself became the laboratory. This is visible in parts of the new emerging sectors of ICT and biotechnology, where most employees have higher formal education and a large part of the workforce and activity is characterized as 'R\&D'. ${ }^{8}$ Science was no longer confined to the laboratory, but scientific thinking and knowledge became part of all aspects of the company. This shift is reflected as well in the organization of production, often relying on 'projects' (consultancy companies, lawyers, architects, etc.) that demand flexibility and a continuous change in firms' internal organization as well as sustained relationships with other firms and partners.

The early Norwegian electronics and computer companies illustrate the extent to which the new 'high-tech' companies were directly an extension of laboratory activities. During the mid-1960s, the companies Norcontrol (1965), AME (1965) and Norsk Data (1967) were established. Norcontrol produced control systems for ships, AME produced semiconductors, and Norsk Data produced computers. All three companies were established as the outcome of research projects in public research institutes and 
universities (SINTEF/NTH in Trondheim; Sentralinstituttet in Oslo; Defence Research Establishment at Kjeller). The research projects were transferred into a new organizational setting defined as a company that would produce income for the researcher-entrepreneurs (many of whom had been research engineers in the research institutes or universities where the firms emerged). The R\&D intensity of these companies remained extremely high for a long period of time (Basberg 1985), reflecting their status as laboratories organized as commercial companies.

The creation of these firms was based on a broader public institutional set-up designed to promote such spinoffs. Through the research council (NTNF), the Development Fund (Utviklingsfondet), public R\&D contracts, and public procurement systems, companies were able to raise public capital to support their technology development processes and to find initial markets in the public sector. (Wicken 2007) The companies remained in close contacts with the public research institutes and universities, and developed close links with other laboratories, with public procurement agencies and with other public sector organisations (NTNF, Utviklingsfondet) supporting the development of new industries. Many of these firms also collaborated with one another, as in Norsk Data's development of computers for the control systems of Norcontrol. ${ }^{9}$ (Sogner 2007)

The companies belonging to this path interact in learning processes with external public labs and universities, as well as with other companies and organisations that have similar science-based production organization. Most of the individuals in these networks have higher education in science, informatics or technology, and many of them have 
backgrounds in the public research institutes. The emerging path thus involved interaction among various 'higher education/high tech' organisations.

\section{R\&D intensive industry and transformation of old paths}

Few if any of the Norwegian companies characterized by this type of innovation processes successfully moved into mass production, instead remaining companies that continuously change products and often develop tailor-made solutions for other companies or public users. In this role the 'Development' aspect of R\&D remains an important part of production costs. The role of the companies is similar to that of the mechanical engineering companies from the $19^{\text {th }}$ century, which became core players in the innovation system for small-scale industrialization. The companies of the new path are organisations that develop new technologies or services used by other sectors of the economy to improve their performance. An excellent case is the history of Simrad, which has developed technologies deployed in fisheries, shipping and the offshore sector on various sub-sea technologies.

Large parts of the ICT industry in Norway emerged as producers of technologies for solving problems in other sectors, and particularly problems relating to Norway's resource endowment (e.g., mountainous terrain, extensive reliance on fisheries and shipping, etc.). The early electronics research projects and production became important for the modernization of fisheries, telecommunication, and eventually, to the modernization of offshore energy production. Collaboration among the old Marine Research Institute, the new Defence Research Establishment (NDRE) and a new 
company, Simrad, resulted in production of echo sounders and later sonars for detection of fish. (Sogner 1997) NDRE also helped develop radio link-based telephone systems, which were particularly well suited for a mountainous nation such as Norway. The link system turned the natural disadvantage into a comparative advantage: Mountains were excellent locations for link stations, and the technology was widely diffused. During the 1960s the Norwegian telecommunications industry and research establishment focused on satellite communications for the shipping industry, seeking to develop a system that would make communication between ships all over the world and the shipping company in Norway much more efficient. More recently, satellites have been used also for managing resource exploration and exploitation in Norway's vast economic zone in the North Sea, the Norwegian Sea, and the Barents Sea. (Collett 1995) The automation industry focused on developing technology for the automation of ships, and control systems for regulating processes in metals, chemical and paper production. Automatic line systems were developed for the fishing industry.

The new technologies were integrated into and used by new and more flexible forms of organization. New process technology and extensive use of ICT combined with new forms of organization and management, created new challenges and opportunities for older industrialization paths. Although some parts of the large-scale industry were challenged by these new types of organizations and technologies, some older small-scale industries were revitalized by them. The shipbuilding and ship equipment industries illustrate the latter possibility. Through use of R\&D and scientific knowledge as well as ICT, close collaboration between producers and between users and producers, and new 
forms of organization of production, these older industries developed new forms of “flexible production”. (Andersen 1997)

The emerging R\&D-intensive form of production also supported problem-solving in sectors that were not linked to resource-based industries and the natural endowment. During its period of success Norway's computer industry provided the public sector with equipment and software for rationalization of administrative processes, and considerable resources were directed towards solving problems for the defense sector. In retrospect, these emerging technologies appear to have been effective instruments for solving challenges in other sectors, although they did not meet the more expansive expectations of the "modernizers" for transformation of Norway’s economy. The strategy for industrial expansion and reindustrialisation based on new technological areas like information technology, biotechnology, new materials and technologies for the oil and gas sector, was dominant for a relatively brief period during the 1980s. Indeed, by this time, the emerging ICT and biotechnology industries were already becoming incorporated into the two largest export sectors; oil and gas and fish. These sectors had discovered the great potential for profit and contracts in the expanding national offshore sector. Many companies turned away from export markets and focused on the growing domestic investment markets. (Sogner 2007)

\section{Conclusions: The Norwegian Innovation System}

This historical description of the Norwegian national innovation argues that the system should not be regarded as a homogenous one with a single structure or institutional set- 
up. Rather, the national innovation system should be seen as the outcome of multiple path-dependent processes of historical evolution and interaction. A specific 'innovation structure' has been established linked to each path, and each of these structures may be regarded as a layer of the wider national innovation system. Each layer consists of specific types of organizations and institutions, with separate knowledge bases and they involve different types of social groups.

Three paths with corresponding layers have been identified and described:

- Small scale decentralized path

- Large scale centralized path

- R\&D intensive network based path

The national innovation system therefore consists of three distinct layers of innovation structures with specific institutional set-ups that shape how innovation and interactive learning processes take place in different sectors of the economy. The three main paths have distinctly different relationships to R\&D:

-Small scale decentralized industries do not perform R\&D

-Large scale centralized industries perform in-house R\&D in separate laboratories $-R \& D$ intensive network based industries perform $R \& D$ in the ordinary production

These characteristics create different forms for interactions between companies and other organizations in innovation processes. 
The small scale decentralized industries rely on public knowledge infrastructure (Smith 2002) for diffusion of knowledge to industries. Norway developed a strong public R\&D infrastructure for primary industries and for other parts of the small-scale decentralized path (Wicken 2007). In addition, industry in this path is dependent on scientific and formal knowledge embedded in physical equipment and inputs into the industry. Knowledge flows through capital equipment and other inputs from scientific organizations and capital goods producers into the non-R\&D performing companies typify this sector.

The large-scale centralized industries have a strong formal knowledge base, including scientific personnel in laboratories, and these experts often constitute a core group in the development of new products and processes. The scientists in the laboratories regularly collaborate with colleagues in universities and research institutes in specific projects, and this collaboration frequently develops into closer relationships that blur the line between the industrial lab and the research institute/university. In Norway, a large part of the technical-industrial research institutes (incl. SINTEF) appear to focus their R\&D on the type of innovation processes characteristic of this sector. (Gulbrandsen and Nerdrum 2007b, 2007c) This type of company also collaborates with various parts of the engineering industries in designing new large scale process technologies, relying on close user-producer relationships.

The R\&D-intensive form of production represents the 'production unit as a laboratory' where $R \& D$ is incorporated into the production process, often organized as projects. A 
larger share of the employees of this type of industry has advanced technical education, and these firms interact closely with other firms or organizations that use and develop science-based knowledge. The public sector and policy institutions have been important part of the innovation infrastructure for this sector, and are often involved in development and innovation processes.

Such heterogeneity in the structure and evolution of different "layers" of national innovation systems is hardly unique to Norway, although the importance of each path and layer may vary considerably, and also the relationship between layers may be different due to specific historical processes and contemporary social context. In Norway the small scale decentralized form of industrialization is still dynamic and the strong fishery and fish farming industry is one of the country's main export sectors. (Aslesen 2007) However, the dominant form or economic organization in modern Norwegian industry is the large-scale centralized structure, reflecting the important role of natural resourcebased industries.

The R\&D intensive network based path to a large extent has become an enabling sector for both the small-scale and large-scale paths of Norwegian industrialization. (Pol et al. 2002). The offshore sector is particularly important for attracting high tech industries, knowledge intensive business services, large parts of engineering and capital goods industries, as well as the research institute sector. (Grønning et al. 2006) The contemporary Norwegian innovation system is particularly strong in enabling sectors that serve the large-scale resource-based industries. The demand from these sectors for 
knowledge and other inputs, as well as sustained political support for their activities, have resulted in a specific structure for interactive learning in the economy that defines a core aspect of the Norwegian innovation system and its specific characteristics: large scale innovation projects in the North Sea and other large natural resource-based industries attract resources and attention from significant parts of the domestic 'enabling' industries. Much of the innovative activity in Norway's economy today is linked to learning processes within this part of the economy. 


\section{Notes}

${ }^{1}$ Since the 1980s a large part of the literature discussing the Industrial Revolution in Britain has focused on the importance of small scale - workshop type - production in addition to the traditional emphasize on the factory as the core institution. This was certainly also the case for large parts of Scandinavian industrialization (Bruland 1991).

${ }^{2}$ Herrigel (1996) in a study on Germany's industrialization uses the concept decentralized for industrial organizations where firms had to adapt to existing norms and rules of the surrounding social environment, and 'centralized' for industrial organizations able to influence or shape its institutional set-up.

${ }^{3}$ The concept of path creation is rather recently introduced into the discussion of innovation, and will here be used as the beginning of a process which over time creates a new form of production drawing on new forms of knowledge, new forms of organisations, as well as involving new social groups.

The concept has also been used in analysis of how companies develop new products which give the company new opportunities for development within new sectors (Garud and Karnoe 2002) and also how micro innovations may influence wider national development and create a new long term development (Schienstock 2004). Mowery and Rosenberg (1998) show how a technological-industrial innovation (production of exchangeable components) created the basis for a new direction in American industrial history. The idea that new technologies and innovations have created basis for new forms of industrialisation is well known in economic history, i.e. inherent in the concept of 'industrial revolutions' (Bruland and Mowery 2004).

${ }^{4}$ Modern meteorology (Bjerknes), marine biology (Sars, Helland Hansen), oceanography, geochemistry (Goldtschmidt)

${ }^{5}$ Arendal Fossekompani, Bjølvefossen, Titan, Det Norske Nitridaktieselskap, Arendal Smelteverk, grong Gruver

\footnotetext{
${ }^{6}$ Literally : Laboratory for Raw Materials

${ }^{7}$ We should note that the first Frascati manual for 1963 explicitly expresses that 'R\&D' is a different concept from 'science'. However, in most innovation literature the two concepts are used more or less synonyms.
}

8 The state has played a crucial role in the development of this type of industry, not only in funding R\&D and subsidizing companies, but in particular as 'initial market' or ' first costumer' for new products. This is also part of the reason that this path involves different type of actors and organizations compared to earlier paths, as state agencies have been involved directly in the formation of the path. 


\section{References}

Andersen, K.G. \& Yttri, G. (1997), Et forsøk verdt. Forskning og utvikling i Norsk Hydro gjennom 90 år, Universitetsforlaget Oslo

Andersen, K.G. (2005), Flaggskip i fremmed eie. Norsk Hydro 1905-1945, Oslo

Andersen, H.W (1997), "Producing producers: shippers, shipyards and the cooperative infrastucture in the Norwegian maritime complex since 1850", in C.F. Sabel og J. Zeitlin, Worlds of Possibilities. Flexibility and Mass production in Western Industrialization, Cambridge University Press

Asheim, B.T (2000), "TESA bedrifter på Jæren - fra territorielt innovasjonsnettverk til funksjonelle konserndannelser?", in A. Isaksen (red.), Regionale innovasjonssystemer, STEP report R-02 1999, Oslo

Aslesen, H.W. (2007), "The innovation system of Norwegian aquacultured salmonids", TIK Working Papers on Innovation Studies, Centre for Technology, Innovation and Culture, Oslo.

Basberg (1986), B.L. Basberg, "R\&D performance in Norwegian Electronics Companies 1960-1975”, Working paper no 26 Norsk elektronikkindustri 1945-1970, Oslo

Berg, B.I (1988), “Gruveteknikk ved Kongsberg Sølvverk 1623-1914”, STS Rapport no. 37, Trondheim

Bergh, T. (1977) "Økonomi og politikk", i T. Bergh og H. Pharo (eds.), Vekst og velstand, Oslo 1977

Bergh \& Lange (1989), Foredlet virke. Historien om Borregaard 1889-1989, Ad Notam forlag, Oslo

Bjørgum, J. (1968), Venstre og kriseforliket, Oslo

Bruland, K. (1989), British technology and European industrialization. The Norwegian textile industry in the nineteenth century, Oxford University Press, Oxford

Bruland, K. (ed.) (1991), Technology transfer and Scandinavian industrialization, New York

Bruland, K. (2000), “Skills, Learning and the International Diffusion of Technology: a perspective on Scandinavian Industrialization, in M. Berg and K. Bruland (eds.), Technological Revolutions in Europa. Historical Perspectives, Edward Elgar, Cheltenham 
Bruland, K. and Mowery, D.C. (2004), “Innovation Through Time”, in Fagerberg, Mowery and Nelson (eds.), The Oxford Handbook of Innovation, Oxford

Chandler, A.D. (1990), Scale and scope: the dynamics of industrial capitalism, Cambridge Mass.

Collett, J.P. (ed.) (1995), Making Sense of Space. The History of Norwegian Space Activities, Universtitetsforlaget, Oslo

Engen, O.A. (2007), “The development of the Norwegian Petroleum Innovation System: A historical overview”, TIK Working Papers on Innovation Studies, Centre for Technology, Innovation and Culture, Oslo.

Fagerberg, J., Mowery, D.C. and Nelson, R.R. (2004), The Oxford Handbook of Innovation, Oxford University Press, Oxford.

Friedman, R.M (1989), Appropriating the Weather: Vilhelm Bjerknes and the Construction of a Modern Meteorology. Ithaca and London: Cornell University Press, 1989

Furre, B. (1971) Mjølk, bønder og tingmenn, Oslo

Garud, R. and Karnoe, P. (2002), Path Dependency and Creation, Lawrence Erlbaum Associates

Grimnes, O.K. (2001), Sam Eyde - den grenseløse gründer, Aschehoug, Oslo

Grønning, T., Moen, S.E. and Olsen D.S. (2006), "Norway: low innovation intensity, high growth and specialized trajectories", unpublished paper

Gulbrandsen, M. and Nerdrum, L. (2007a), "Public R\&D and Industrial Innovation in Norway - a historical perspective”, TIK Working Papers on Innovation Studies, Centre for Technology, Innovation and Culture, Oslo.

Gulbrandsen, M. and Nerdrum, L. (2007b), “University-Industry Relations in Norway”, TIK Working Papers on Innovation Studies, Centre for Technology, Innovation and Culture, Oslo.

Gulbrandsen, M. and Nerdrum, L. (2007c), “The technical-industrial research institutes in the Norwegian innovation system”, TIK Working Papers on Innovation Studies, Centre for Technology, Innovation and Culture, Oslo.

Hanisch, T.J and Lange, E. (1985), Vitenskap for industrien : NTH - en høyskole i utvikling gjennom 75 år, Oslo 
Hanisch, T.J. and Nerheim, G. (1992), ”Fra vantro til overmot?”, vol 1 of Norsk oljehistorie, Norsk Petroleumsforening, Oslo

Herrigel, G. (1996), Industrial Constructions: The sources of German industrial power, Structural analysis in social sciences 9, Cambridge University Press, New York

Hughes (1983), Networks of Power, Baltimore

Kjeldstadli, K. (1988), Jerntid. Fabrikksystem og arbeidere ved Christiania Spigerverk og Kværner Brug fra om lag 1890 til 1940, dr philos dissertation, University of Oslo

Kjeldstadli, K. and Myhre, J.E. (1995), Oslo - spenningenes by, Oslo

Kjeldstadli, K., Myklebust, S. and Thue, L. (eds) (1994), Forminga av industrisamfunnet i Norden fram til 1920, TMV report no. 5

Landes, D.S (1969), The unbound Prometheus : technological change and industrial development in Western Europe from 1750 to the present, Cambridge University Press, Cambridge

Lange, E. (1977), “The Concession Laws of 1906-1909 and Norwegian Industrial Development”, Scandinavian Journal of History, 2/1977

Lundvall, B-Å. (1992), National Systems of Innovation. Towards a Theory of Innovation and Interactive Learning, Pinter Publishers, London

Moen, S.E. (2007), "Innovation and Production in the Norwegian Aluminium Industry", TIK Working Papers on Innovation Studies, Centre for Technology Innovation and Culture, Oslo.

Mowery, D.C and Rosenberg, N. (1989), Technology and the pursuit of economic growth, Cambridge

Mowery, D.C. and Rosenberg, N. (1998), Paths of Innovation : technological change in 20th-century America, Cambridge

Narula, R. (2002), “Innovation systems and 'inertia' in R\&D location: Norwegian firms and the role of systemic lock-in”, Research Policy, Volume 31, Issue 5

Nielsen, T.H., Monsen, A. and Tennøe (2000), T., Livets tre og kodenes kode : fra genetikk til bioteknologi : Norge 1900-2000, Gyldendal, Oslo

NTNF (1964), NTNF’s forskningsutredning 1964, Oslo 
Pol, E., Carroll, P., Robertson, P. (2002), A new Typology for Economic Sectors with a View to Policy Implications, Economic Innovation and New Technologies, vol.11(1), pp.61-76

Randers, G. (1953), Atomenergi som industriell kraftkilde, Kjeller 1953

Refsdal, A.-O. (1973), ”Nyetablering og krise - en undersøkelse av bedriftsdannelse innen industri, håndverk og handel under krisen i 1930-åra”, master thesis in history, University of Oslo

Rosenberg (1972), N. Rosenberg, Perspectives on technology, Cambridge University Press, Cambridge

Schienstock, G. (2004), "From path dependency to path creation: A new challenge to the systems of innovation approach”, in Schienstock, G. (ed.) Embracing the Knowledge Economy: The Dynamic Transformation of the Finnish Innovation System, Cheltenham, UK: Edward Elgar Publishing Ltd

Schwach (2002), V. Schvach, Havet, fisken og vitenskapen : fra fiskeriundersøkelser til havforskningsinstitutt 1860-2000, Oslo

Sejersted, F. (1982) (ed), Vekst gjennom krise. Studier i norsk teknologihistorie, Universitetsforlaget Oslo

Sejersted, F. (1993), Demokratisk kapitalisme, Universitetsforlaget Oslo

Sejersted, F. (2005), Den sosialdemokratiske tidsalder: Norge og Sverige i det 20. århundre, Oslo

Slagstad, R. (2001), De nasjonale strateger, Oslo

Smith, K. (2002), ’Innovation infrasturcture”, working paper at UNU/Intech July 30, Maastricht

Sogner, K. (1997), God på bunnen : Simrad-virksomheten 1947-1997, Novus Forlag, Oslo

Sogner, K. (2001), Plankeadel : Kiær-og Solberg-familien under den 2. industrielle revolusjon, Oslo

Sogner, K. (2002), ”Det norske næringsborgerskapet under den andre industrielle revolusjon”, Scertrykk Handelshøyskolen BI, no. 35

Sogner, K. (2004), Creative power : Elkem 100 years : 1904-2004, Oslo 
Sogner, K. (2007), "Biotechnology business in Norway: Peripheral advantage of just periphery?”, TIK Working Papers on Innovation Studies, Centre for Technology, Innovation and Culture, Oslo.

Sundt (1975), Om husfliden i Norge, Verker i utval, vol 8, Oslo

SØS 12 (1963), ”Norsk økonomi i etterkrigstiden”, Statistisk økonomiske studier, vol 12, Statistisk Sentralbyrå, Oslo

Thue, L. (1994), Statens Kraft 1890-1947. Kraftutbygging og samfunnsutvikling, Cappelen, Oslo

Wicken, O. (1983), O. Wicken, “Technological Change in Norway during Second World War”, Scandinavian Journal of History

Wicken, O. (1984), “Learning, Inventions and Innovations. Productivity increase and new technology in an industrial firm, The Scandinavian Economic History Review

Wicken, O. (1989), ”Norsk verkstedsindustri markedsorientering”, in E. Lange (ed.), Teknologi i virksomhet: verkstedindustri i Norge etter 1840, Oslo

Wicken, O. (ed.) (1994), Elektronikkentreprenørene. Studier av norsk elektronikkforskning og-industri etter 1945, Ad Notam Gyldendal Oslo

Wicken, O. (2005), "Diverse regional industrialisation : Norway during the first half of the 20th century", in Bruland K. and Olivier. J.-M. (eds), Essays on industrialisation in France, Norway and Spain, Tid og Tanke, Oslo

Wicken, O. (2007), "The Role of R\&D in Industrial Policy: Rise and fall of a researchdriven strategy for industrialization”, TIK Working Papers on Innovation Studies, Centre for Technology, Innovation and Culture, Oslo. 


\section{Box1: Small scale decentralized path}

- Small scale companies

- Production processes normally characterized by low capital intensity

- Local knowledge and open exchange of information and learning in local community

- Open search for information abroad or in other regions of Norway

- Institutional set-up defined by the local community (companies to accept 'rules of the game' established by other firms and local institutions

- No or little internal R\&D, but expanding use over time of science-based flows of knowledge and technologies 


\section{Box2: The large scale centralized path}

- Large scale of organization

- Production often is capital-intensive

- Firms are able to shape their own environment and influence the 'rules of the game’

- Systematic search for relevant knowledge - specialized expertise hired by company

- Internal research processes organized in separate laboratories or development departments

- Collaborative learning with other companies and/or research communities

- Collective, individual and hierarchical learning processes in the work place 


\section{Box 3: R\&D intensive network based path}

- Production unit as a laboratory: R\&D incorporated in the production process

- $\quad$ R\&D-intensive rather than capital-intensive

- Often organized around projects and problem solving activities (flexible)

- Collaborate with other companies or research organizations in innovation and production networks that include public and private organizations

- Institutions established as outcome of interactive processes among different types of organizations and the environment; no dominant actor shapes the institutional set-up 


\section{Box 4: Conflicts between paths - The Battle of Trollfjorden 1890}

Challenges to old forms of production have some times taken dramatic forms, and the dramatic events have shaped long term development. The battle of Trollfjorden is one of these events. Trollfjorden is located in one of the world's richest fishing ground for cod in Lofoten. In 1890, a British steamship closed off parts of the fiord with a huge net, and invited local fishermen to catch fish for the vessel. The fishermen revolted and attacked the ship physically in a dramatic episode that has been retold to younger generations through the book 'The Last Viking' by Johan Bojer. The local fishermen reacted because they saw the incident as a challenge to their social status as self employed. They were invited to become salary earners - a proletariat - for foreign capitalists. After the 'Battle of Trollfjorden,' the Storting adopted laws that stopped foreign steel-steam-trawl fishing vessels from taking part in the yearly cod fishery at Lofoten. This was the beginning of a long tradition of protecting small-scale fishing vessels in coastal fishing areas, particularly in Northern Norway, that became the main institution for protection of the fisher-farmer lifestyle during the $20^{\text {th }}$ century. 


\section{Box 5: The politics of Norwegian electricity - Competition between paths}

A major conflict in the Norwegian society was how the emerging electrical energy resource should be used to promote social development. Two major ideologies competed. Most politicians and a majority of the people preferred the development of small-scale and local electricity works, financed by local communities. This pattern of development would support the small scale decentralised form of industrialisation. Supporters of this approach argued that electricity could provide light for households and become an energy source for small-scale electric farms and industry

The opposing group saw large scale electricity works as the basis for large-scale industrialisation, relying if necessary on foreign capital and more centralised planning and coordination. This approach was supported by representatives from large-scale industry, as well as engineers and technocrats in all political parties. Gradually this ideology gained became influence in the Labour Party, and Labour governments supported this form of industrialisation after the end of WWII (Thue 1994). 


\section{Box6: The modernizers}

A group of Norwegian scientists and engineers became involved in wartime research institutions in the UK and the USA during WWII, and after the war tried to introduce the knowledge and technologies that they had developed during wartime into the Norwegian context. The learning processes in allied laboratories during WWII influenced the establishment the civil (NTNF) and a military (FFI) research systems in 1946. These organizations promoted new technologies, such as nuclear energy, missiles, fire control systems, weapons systems, telecommunication systems, space technology, automation or regulation technology, electronics, computers, and software programming.

The modernizers argued that these emerging technologies would contribute to the modernization of Norway's economy and society, improving performance in old industries like fisheries and process industries, as well as in such key components of public infrastructure as telecommunication, defence, and public administration. These new technologies also were expected to become the basis for future growth sectors and export industries.

This ideology became influential in Norwegian politics from the mid 1960s onwards. Its influence peaked during the 1980s, when it was widely accepted that the emerging technologies would become the basis for Norwegian reindustrialization. Since the early 1990s, however, this ideology had become much weaker in Norwegian politics. 